\title{
PERANAN KELOMPOK TANI DALAM PENGELOLAAN MADU LEBAH HUTAN (APIS DORSATA FABRICIUS) OLEH MASYARAKAT DI DESA NANGA LEBOYAN KECAMATAN SELIMBAU KAWASAN DANAU SENTARUM KABUPATEN KAPUAS HULU
}

(The Role of Farmer Groups in the Management of Forest Honey Bees (Apis Dorsata Fabricius) By Communities in Nanga Leboyan Village Selimbau District Lake Sentarum Area Kapuas Hulu Regency)

\author{
Laila Quratul Aini, Iskandar, Gusti Hardiyansyah \\ Fakultas Kehutanan Universitas Tanjungpura, Jalan Imam Bonjol Pontianak 78124 \\ Email: lailaquratulaini8@gmail.com
}

\begin{abstract}
Sustainable management of forest honey requires an organization especially to guarantee forest honey quality standards in terms of naturalness which can be in the form of farmer groups. This study aims to reveal the role of farmer groups in the management of forest honey bees. This research is expected to provide information on how the role of farmer groups in the management of forest honey bees by the community in Nanga Leboyan Village, Selimbau District, Danau Sentarum Regency, Kapuas Hulu Regency. This research was conducted by conducting direct interviews with forest honey bee farmer groups. Information about the role of farmer groups in forest honey bee management was obtained during interviews and direct observations in the form of honey management processes, the role of farmer groups in institutions, production, capital, and the relationship between the role of farmer groups and the productivity of honey farming presented in tables, figures and The photo is then analyzed descriptively qualitatively. The results of interviews with 70 members of the honey farmer group showed that the process of forest honey management in Nanga Leboyan Village was carried out according to stages, starting from the initial installation of the bend to post-harvest. Farmer groups play an important role in their institutions, production and capital. The relationship between the role of farmer groups with the productivity of honey farming in Nanga Leboyan Village can be positively related to increasing honey production.
\end{abstract}

Keywords: farmer groups, forest honey bee management, Role.

\section{PENDAHULUAN}

Menurut Rachim et al. (2011) Pengelolaan madu hutan lestari memerlukan organisasi terutama untuk menjamin standar kualitas madu hutan dari sisi kealamiannya serta menjaga kelestarian pohon sialang yang dapat berbentuk kelompok tani. Kelompok tani diartikan sebagai kumpulan orangorang tani atau terdiri dari petani dewasa (pria/wanita) maupun petani taruna (pemuda/pemudi yang terikat secara formal dalam suatu wilayah keluarga atas dasar keserasian dan kebutuhan bersama serta berada di lingkungan dan dipimpin seorang ketua (Mardikanto, 2003).

Desa Nanga Leboyan merupakan salah satu desa yang tedapat di Kecamatan Selimbau, Kabupaten Kapuas Hulu yang memiliki jumlah penduduk sekitar 400 jiwa. Secara administrasi Desa Nanga Leboyan ini sendiri terletak dikawasan Taman 
Nasional Danau Sentarum dengan luas wilayah 35.080 hektar. Masyarakat Desa Nanga Leboyan dalam membudidayakan lebah madu dengan menggunakan menerapkan sistem tikung, yaitu menggunakan sejenis kayu yang dipasang pada dahan-dahan pohon sebagai tempat bersarangnya lebah.

Kawasan Danau Sentarum terdapat lembaga APDS (Asosiasi Periau Danau Sentarum). APDS merupakan salah satu lembaga asosiasi periau (kelompok petani madu) tertua di Kapuas Hulu yang dibentuk sejak 21 Juli 2006. APDS sampai tahun 2018 sudah menaungi 14 kelompok periau (kelompok petani madu) dari seluruh kampung (Dusun) yang ada di kawasan Danau Sentarum. Satu kelompok ratarata terdiri dari 5-40 petani dan anggota petaninya sekitar 301 orang salah satu kelompok tani APDS adalah periau (kelompok tani madu) Dusun Batu Rawan Semangit Desa Nanga Leboyan yang sampai sekarang masih terus melakukan pengelolaan madu lebah hutan. Dusun Batu Rawan ini sendiri terdiri dari 39 orang anggota yang telah bergabung dalam periau dari 400 jiwa jumlah penduduk yang ada. Adapun luas lahan yang dikelola bagi para petani madu di kawasan ini sesuai dengan data tahun 2007 mencapai 7.300 hektar.

Ide membuat suatu kelompok berasal dari kenyataan bahwa setiap individu tidak akan dapat memenuhi kebutuhan dan harapan seorang diri. Individu terutama dalam masyarakat modern, merasa kurang mampu, kurang tenaga, kurang waktu dan tidak berdaya bila harus memenuhi sendiri kebutuhan dasar atas makanan, naungan dan keselamatan. Bekerjasama dalam kelompok adalah lebih mudah dari pada kunjungan individu. Penyuluhan pertanian jumlahnya jelas terbatas, berarti bekerjasama dengan kelompok lebih rendah biayanya. Alasan terbentuknya suatu kelompok adalah oleh karena beberapa orang mempunyai persoalan yang sama (Rusdi, 1999).

Penelitian ini bertujuan untuk : mengungkapkan proses-proses pengelolaan madu hutan, peranan kelompok tani dalam pengelolaan madu dan hubungan antara peran kelompok tani dengan produktivitas usahatani masyarakat.

\section{METODE PENELITIAN}

Penelitian ini dilaksanakan di Desa Nanga Leboyan Kecamatan Selimbau Kawasan Danau Sentarum Kabupaten Kapuas Hulu, selama 1 (satu) bulan efektif dilapangan yaitu dari tanggal 14 Juni 2019 sampai 15 Juli 2019, dilanjutkan dengan mengolah dan menganalisis data.

Penelitian ini menggunakan metode survey dengan teknik wawancara. Pengambilan sampel/responden dilakukan secara sampling kelompok dua tingkat. Objek penelitian ini adalah peran kelompok tani. Data yang diperoleh di lapangan disajikan dalam bentuk tabel, gambar dan foto kemudian dianalisa secara deskriptif kualitatif. Rangkuman data peran kelompok tani yang diperoleh meliputi: teknik-teknik tikung yang diterapkan, syarat-syarat 
pemanenan madu hutan, proses panen madu, peran kelompok tani dalam kelembagaan, peran kelompok tani dalam produksi, peran kelompok tani dalam modal, hubungan antara peran kelompok tani dan produktivitas usahatani.

\section{HASIL DAN PEMBAHASAN}

1. Karakteristik Responden

\section{- Berdasarkan Umur}

Karakteristik Tingkat Umur Responden

Dusun Batu Rawan Semangit dapat dilihat pada tabel 1 dibawah ini

Tabel 1. Karakteristik Responden Berdasarkan Tingkat Umur (Characteristics of Respondents by Age Level)

\begin{tabular}{cccccc}
\hline \multirow{2}{*}{ No } & $\begin{array}{c}\text { Tingkat } \\
\text { Umur }\end{array}$ & \multicolumn{2}{c}{ Kelompok } & \multicolumn{2}{c}{ Tidak bergabung } \\
& (tahun) & Jumlah & Persentase & \multicolumn{2}{c}{ Kelompok Tani } \\
& $20-30$ & 0 & 0.00 & 0 & Persentase \\
\hline 1 & $31-40$ & 3 & 8.57 & 5 & 0.00 \\
2 & $41-50$ & 20 & 57.14 & 17 & 14.29 \\
3 & $51-60$ & 11 & 31.43 & 9 & 48.57 \\
4 & 1 & 2.86 & 1 & 25.71 \\
5 & $61-70$ & 35 & 100.00 & 35 & 100.00 \\
\hline
\end{tabular}

\section{- Berdasarkan Jenis Kelamin}

Hasil penelitian, jenis kelamin responden semuanya laki-laki (100\%) yaitu 35 orang untuk yang bergabung dalam kelompok tani dan 35 orang yang tidak bergabung dalam kelompok tani, laki-laki masih mendominasi pekerjaan masyarakat di Dusun Batu Rawan Semangit. Hal ini disebabkan karena laki-laki pada umumnya yang bekerja mencari nafkah untuk rumah tangganya sebagai petani madu lebah hutan di Dusun Batu Rawan Semangit. Kegiatan

Table 2. Karakteristik Responden Berdasarkan Tingkat Pendidikan (Characteristics of Respondents by Education Level)

\begin{tabular}{cccccc}
\hline \multirow{2}{*}{ No } & $\begin{array}{c}\text { Tingkat } \\
\text { Pendidikan }\end{array}$ & \multicolumn{2}{c}{$\begin{array}{c}\text { Kelompok } \\
\text { Tani }\end{array}$} & \multicolumn{2}{c}{$\begin{array}{c}\text { Tidak bergabung } \\
\text { Kelompok Tani } \\
\end{array}$} \\
& SD & 31 & 88.57 & 27 & 77.14 \\
1 & SMP & 4 & 11.43 & 8 & 22.86 \\
2 & SMA & 0 & 0.00 & 0 & 0.00 \\
3 & Jumlah & 35 & 100.00 & 35 & 100.00 \\
\hline
\end{tabular}

pertanian dibeberapa daerah masih identik dengan pekerjaan laki-laki. Hal ini didukung oleh Purba (2016) menyatakan kegiatan pertanian sering diindentikkan dengan kaum laki-laki, sehingga beberapa kelompok pertanian yang bersifat umum kebanyakan dilakukan oleh laki-laki.

\section{- Berdasarkan Pendidikan}

Karakteristik

Responden Berdasarkan Pendidikan dapat dilihat pada tabel 2 dibawah ini. 


\section{- Proses-proses Pengelolaan Madu \\ Kelompok Tani dan yang tidak bergabung Kelompok Tani}

Berdasarkan hasil rekapitulasi hasil wawancara dengan responden mengenai proses pengelolaan madu oleh kelompok tani dan yang tidak bergabung kelompok tani baik dari tahapan awal pembuatan tikung sampai dengan pasca panen madunya yang berupa teknik-teknik tikung, syaratsyarat pemanenan madu hutan dan proses panen madunya dapat dilihat pada Tabel 3 dibawah ini.

Tabel 3. Proses-Proses Pengelolaan Madu Hutan Alam Teknik Tikung Masyarakat Kelompok Tani dan Masyarakat yang tidak bergabung Kelompok Tani Mulai dari Tahapan Awal sampai Pasca Panen di Dusun Batu Rawan Semangit (Processes of Natural Forest Honey Management Technique Tikung Peasant Community Groups and Communities that do not join Farmer Groups Starting from the Initial Stages to Post Harvest in Batu Rawan Semangit Sub Village)

\begin{tabular}{|c|c|c|c|}
\hline No & $\begin{array}{c}\text { Proses Pengelolaan } \\
\text { Madu } \\
\end{array}$ & Masyarakat Kelompok Tani & $\begin{array}{c}\text { Masyarakat yang tidak } \\
\text { bergabung Kelompok Tani }\end{array}$ \\
\hline 1 & $\begin{array}{l}\text { Teknik-teknik } \\
\text { tikung }\end{array}$ & $\begin{array}{l}\text { - Jenis kayu yang digunakan } \\
\text { Tembesu }\end{array}$ & $\begin{array}{l}\text { - Jenis kayu yang digunakan } \\
\text { Kawi }\end{array}$ \\
\hline 2 & $\begin{array}{l}\text { Syarat-syarat } \\
\text { pemanenan } \\
\text { madu hutan }\end{array}$ & $\begin{array}{l}\text { - Perlengkapan pisau stainless, } \\
\text { wadah, penutup muka dan } \\
\text { akar kayu menyadin(tebaok) }\end{array}$ & $\begin{array}{l}\text { Perlengkapan pisau biasa, } \\
\text { wadah, penutup muka dan } \\
\text { akar menyadin(tebaok) }\end{array}$ \\
\hline 3 & $\begin{array}{l}\text { Proses panen } \\
\text { madu }\end{array}$ & - Waktu panen siang hari & - Waktu panen malam hari \\
\hline
\end{tabular}

\section{- Teknik-teknik tikung}

Hasil penelitian mengungkapkan bahwa jenis kayu yang sering digunakan dalam pembuatan tikung oleh kelompok tani adalah kayu Tembesu (Fagraeae fragrans). Berdasarkan hasil penelitian yang tidak bergabung kelompok tani menggunakan kayu Kawi (Shorea balangeran) dalam pembuatan tikung. Pemasangan tikung masyarakat kelompok tani APDS dilakukan pada pagi sampai siang hari dikarenakan waktu yang lebih efektif adalah dari jam 8 pagi sampai 2 sore. Tikung yang dipasang setiap tahunnya selalu diperiksa layak atau tidak bagi lebah untuk bersarang lagi. Hadisuesilo (1998) jenis kayu yang 1 dan 2 saling berhadapan atau satu tikung diatas dan satu tikung dibawah. Pemasangan

tikung harus ditengah-tengah
rindangnya pohon dan tidak boleh dipasang pada tajuk pohon dikarenakan banyak faktor yang mengganggu atau merusak tikkun yang sudah dipasang seperti angina rebut dan hewan.

$$
\text { Kuntandi (2007) bahwa }
$$
pemasangan tempat bersarang buatan dapat dilakukan dengan dua cara, tergantung kondisi tanah. Di daerah datar, baik dilahan kering maupun pasang surut (basah), tempat bersarang buatan dipasang diantara dua tonggak (tiang penyangga) atau diantara cabang pohon. Masyarakat yang tidak bergabung kelompok tani membuat tikung dengan ukuran lebih kecil dengan panjangnya yaitu hanya $1,5 \mathrm{~m}$. Pemasangan tikung dilakukan pada pagi sampai sore hari dari jam 9 pagi sampai 
3 sore. Tikung yang dipasang setiap tahunnya selalu diperiksa layak atau tidak bagi lebah untuk bersarang lagi.

\section{- Syarat Pemanenan Madu Hutan}

Hasil penelitian mengungkapkan bahwa perlengkapan yang digunakan saat pemanenan madu berlangsung oleh kelompok tani yaitu harus membawa pisau stainless untuk mengiris madunya, wadah untuk menyimpan madu, penutup muka untuk menghindari sengatan lebah dan akar menyadin (tebaok) dipakai untuk mengusir lebah supaya lari dari sarangnya. Berdasarkan hasil penelitian yang tidak bergabung kelompok tani perlengkapan yang dibawa saat proses panen yaitu membawa wadah, penutup muka, akar menyadin (tebaok) dan yang tidak bergabung kelompok tani menggunakan pisau biasa yang bukan stainless untuk mengiris madunya.

\section{- Proses Panen Madu}

Hasil penelitian waktu yang digunakan untuk proses pemanenan madu kelompok tani yaitu pada siang hari. Berdasarkan hasil penelitian waktu yang digunakan untuk proses pemanenan madu yang tidak bergabung kelompok tani yaitu pada malam hari.

\section{Peranan Kelompok Tani dan yang tidak bergabung Kelompok Tani dalam Pengelolaan Madu}

Berdasarkan hasil rekapitulasi hasil wawancara dengan responden tentang peran kelompok tani dan yang tidak bergabung kelompok tani dalam pengelolaan madu mencakup aspek kelembagaan, aspek produksi dan permodalan dapat dilihat pada Tabel 4 dibawah ini.

Tabel 4. Peranan Masyarakat Kelompok Tani dan yang tidak bergabung Kelompok Tani Madu dalam Pengelolaan Madu Lebah Hutan di Dusun Batu Rawan Semangit (The Role of Community Farmer Groups and those who do not join the Honey Farmers Group in the Management of Forest Honey Bees in Batu Rawan Semangit Sub Village)

\begin{tabular}{|c|c|c|c|}
\hline & Peran & Masyarakat Kelompok Tani & $\begin{array}{c}\text { Masyarakat yang tidak bergabung } \\
\text { Kelompok Tani }\end{array}$ \\
\hline 1 & Kelembagaan & $\begin{array}{l}\text { - Wadah belajar mengajar bagi } \\
\text { anggotanya } \\
\text { - Tempat untuk memperkuat } \\
\text { kerjasama petani } \\
\text { - Memiliki kemampuan mengambil } \\
\text { keputusan dalam menentukan } \\
\text { pengembangan produksi }\end{array}$ & \\
\hline 2 & Produksi & $\begin{array}{l}\text { - Peningkatan kualitas madu } \\
\text { menggunakan sistem tiris } \\
\text { - Peningkatan produksi madu } \\
\text { menggunakan teknik panen } \\
\text { secara lestari }\end{array}$ & $\begin{array}{l}\text { - Peningkatan produksi madu } \\
\text { menggunakan teknik panen } \\
\text { secara lestari }\end{array}$ \\
\hline & Modal & $\begin{array}{l}\text { - Sumber utama swadaya dari } \\
\text { anggota kelompok tani } \\
\text { - Mencari sponsor dari pihak lain }\end{array}$ & $\begin{array}{l}\text { - Modal sendiri/pribadi tanpa } \\
\text { bantuan pihak lain }\end{array}$ \\
\hline
\end{tabular}




\section{- Peran dalam Kelembagaan}

Berdasarkan Peraturan Menteri

Pertanian

Nomor

67/Permentan/SM.050/12/2016 tentang

Pembinaan Kelembagaan Petani, dalam upaya peningkatan kemampuan kelompok tani dalam melaksanakan perannya sebagai kelas belajar (kelompok tani merupakan wadah belajar mengajar bagi anggotanya guna meningkatkan pengetahuan, keterampilan dalam berusahatani), wahana kerjasama (kelompok tani merupakan tempat untuk memperkuat kerjasama diantara sesama petani dalam kelompok tani dan antar kelompok tani serta dengan pihak lain), unit produksi (sebagai unit produksi, kelompok tani diarahkan untuk memiliki kemampuan mengambil keputusan dalam menentukan pengembangan produksi yang menguntungkan). Hasil dari penelusuran melalui wawancara yang dilakukan, ternyata hal ini sudah dirasakan masyarakat di Dusun Batu Rawan Semangit dimana dengan adanya peran kelompok tani menurut anggota APDS menjelaskan bahwa dengan menjadi anggota ini dapat menambah pengetahuan untuk mengelola madu dari pemanenan hingga penanganan pasca panennya. Selanjutnya, dijelaskan oleh masyarakat dengan bertambahnya pengetahuan ini dapat menjaga kualitas madu (higienis) hal ini berdampak pada peningkatan perekonomian masyarakat, dapat memenuhi kebutuhan masyarakat.

Kelompok tani pada hakikatnya adalah untuk menggerakkan sumber daya manusia petani. Pembinaan kelompok tani berperan dalam meningkatkan pengetahuan, sikap dan keterampilan petani (Thomas, 2008). Menurut Djogo et al. (2003) menyimpulkan dan mendefinisikan kelembagaan sebagai suatu tataan dan pola hubungan antara anggota masyarakat atau organisasi yang saling mangikat yang dapat menentukan bentuk hubungan antar manusia atau antar organisasi yang diwadahi dalam suatu organisasi atau jaringan dan ditentukan oleh factor-faktor pembatas dan pengikat berupa norma, kode etik aturan formal maupun informal untuk pengendalian perilaku sosial serta intensif untuk bekerjasama dan mencapai tujuan bersama.

Berdasarkan hasil penelitian petani yang tidak tergabung kelompok tani tidak mendapatkan pengetahuan, keterampilan dalam berusahatani yang baik dan benar serta bagaimana rasa kerjasama dengan petani lainnya karena petani yang tidak bergabung kelompok tani merupakan masyarakat individu jadi pengelolaan madunya sebatas pengetahun individunya.

\section{- Peran dalam Produksi}

Kelompok tani madu hutan Dusun Batu Rawan Semangit berperan aktif dalam kegiatan produksi madu hutan yang berkualitas. Dalam kegiatan produksi kelompok tani menggunakan sistem tiris. Sistem ini merupakan penghasil madu yang higienis tanpa diperas. Sistem tiris ini tidak diketahui oleh anggota kelompok tani karena dari zaman nenek moyang mereka petani untuk mengeluarkan madu dari sarangnya dengan cara diperas sehingga hasiln madunya tidak higienis untuk dikonsumsi. 


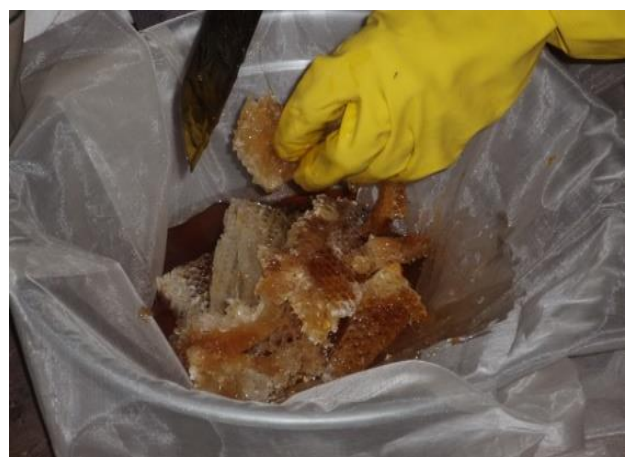

Gambar 1. Sistem tiris madu (honey drain system)

Proses panen lestari adalah teknik pemanenan madu khususnya madu hutan dengan hanya mengambil dan menyisihkan sedikit untuk anakan atau $25 \%$ dari bagian kepala madu yang harus ditinggal. Teknik ini terbukti baik berhasil meningkatkan produksi madu hutan, menghasilkan madu dengan kualitas lebih baik dari proses konvensional, sekaligus membantu pelestarian hutan. Teknik ini dinamakan dengan sistem tiris. Sistem tiris ini akan menghasilkan madu yang lebih higienis dan memiliki rasa yang lebih murni bila dibandingkan dengan madu yang diperoleh dengan sistem peras Rachim et al. (2011).

Hasil penelitian ditemukan pula bahwa selain menerapkan panen lestari dengan meninggalkan $75 \%$ sarang madu kelompok tani juga selalu merawat dan menjaga pohon tempat bersarangnya lebah madu. Sesuai dengan penelitian yang telah dilakukan oleh Sofia (2017) menyatakan bahwa kearifan lokal yang berupa peraturan adat yang dilakukan petani madu Meliau Danau Sentarum Kapuas Hulu yaitu merawat pohon sarang lebah, dan larang menebang pohon sarang lebah serta membuka lahan pertanian dengan membakar hutan secara berlebihan sesuai pula dengan penelitian yang telah dilakukan Jamiat (2019) yang menjelaskan bahwa upaya masyarakat petani madu dikawasan Danau Siawan Belida Kapuas Hulu dalam rangka mempertahankan kelestarian produksi madu alam melalui kearifan lokal menjaga dan mempertahankan vegetasi pakan lebah madu yang berada disekitar Danau. Berdasarkan Peraturan Menteri Pertanian Nomor 67/Permentan/SM.050/12/2016 tentang Pembinaan Kelembagaan Petani dalam upaya peningkatan kemampuan kelompok tani dalam melaksanakan perannya yaitu sebagai unit produksi (kelompok tani diarahkan untuk memiliki kemampuan mengambil keputusan dalam menentukan pengembangan produksi yang menguntungkan) saat ini sudah dirasakan kelompok tani dapat meningkatkan produksi madu oleh pengurus kelompok tani.

Berdasarkan hasil penelitian petani yang tidak bergabung kelompok tani tidak menggunakan sistem tiris dan hanya menggunakan teknik panen secara lestari supaya dapat meningkatkan produksi madunya. 
Walaupun demikian kelompok tani menghasilkan produksi madu lebih banyak dibandingkan dengan yang tidak bergabung kelompok tani hal ini dikarenakan kelompok tani memiliki jumlah tikung lebih banyak dari pada yang tidak bergabung kelompok tani karena syarat masuk anggota kelompok tani harus memiliki minimal 25 tikung untuk satu orang anggota kelompok tani madu.

\section{- Peran dalam Modal}

Kelompok tani madu hutan Dusun Batu Rawan Semangit dalam permodalan berupaya untuk memperoleh modal baik secara swadaya maupun meminta bantuan dari pihak lain. Adanya upaya tersebut, kelompok tani dapat terus melanjutkan kegiatan produksi sehingga pengelolaan madu hutan dapat terus berkembang dan memenuhi kebutuhan masyarakat.

Peran kelompok tani di Dusun Batu Rawan Semangit ini dalam permodalan menunjukkan sumber modal yang diperoleh kelompok tani yang digunakan dalam pemanfaatan madu hutan Dusun Batu Rawan Semangit menunjukkan bahwa kelompok petani mendapatkan modal yang cukup besar dari PT. Dian Niaga sebesar Rp. 135.000.000. Berdasarkan wawancara diperoleh bahwa ada 2 LSM yang sudah memberikan sumber modal sebagai pinjaman ke kelompok tani yaitu : PT. Dian Niaga dan PT. Primaduta Indonesia untuk pemerintah sendiri yang memberikan sumber modal sebagai pinjaman ke kelompok tani yaitu dari BLU (Badan Layanan
Umum) secara swadaya dari anggota. Modal secara swadaya diupayakan oleh para anggota karena untuk memperbesar modal yang ada. Modal secaraswadaya merupakan modal utama sebagai penggerak kelompok tani skala kecil yang modalnya diperoleh kembali dari hasil penjualan.

Modal yang diperoleh berasal dari bantuan PT. Dian Niaga, PT. Primaduta Indonesia, dan BLU (Badan Layanan Umum) berupa uang pinjaman/modal awal bagi petani dan pengadaan alat. Bantuan berupa pinjaman uang juga dijadikan sebagai modal pengadaan alat dan pembelian madu. Pentingnya pengadaan alat dalam memproses hingga mengemas madu yang berkualitas harus didukung dengan modal yang mencukupi. Hal ini didukung oleh Rachim et al. (2011) menjelaskan bahwa salah satu peran kelompok tani adalah mengusahakan permodal (keuangan) dan peralatan. Selanjutnya, dijelaskan bahwa permodalan menjadi hal yang penting bagi kelompok tani karena modal peralatan menjadi hal yang penting misalnya modal untuk sewa tempat, pembelian alat misalnya alat pengurang kadar air, peralatan pemrosesan dan pengemasan.

$\begin{array}{ccc}\text { Menurut } & \text { Gilarso } & \text { (1993), } \\ \text { mengemukakan } & \text { bahwa } & \text { modal }\end{array}$
merupakan sarana atau bekal untuk melaksanakan usaha. Secara ekonomi modal adalah barang-barang yang bernilai ekonomi yang digunakan untuk menghasilkan tambahan kekayaan ataupun untuk meningkatkan produksi. 
Modal dalam usahatani bersamaan dengan faktor produksi lainnya akan menghasilkan produk. Modal ini semakin berperan dengan berkembangnya usahatani tersebut. Pada usahatani sederhana peran modal yang diperlukan kecil, namun semakin maju usahatani modal yang diperlukan besar.

Berdasarkan hasil penelitian petani yang tidak bergabung kelompok tani dalam mengelola madu hutan modal

Tabel 5. Hubungan antara Peran Kelompok Tani dengan Produktivitas Usahatani (The Relationship between the Role of Farmer Groups with Productivity)

\begin{tabular}{llll}
\hline No & \multicolumn{1}{c}{ Hubungan } & \multicolumn{2}{c}{ Masyarakat kelompok tani } \\
\hline 1 & $\begin{array}{l}\text { Peran kelompok tani } \\
\text { dengan produktivitas } \\
\text { usahatani madu }\end{array}$ & $\bullet$ & $\begin{array}{l}\text { Dapat mendorong meningkatnya } \\
\text { produksi madu yang dihasilkan }\end{array}$ \\
\hline
\end{tabular}

Berdasarkan hasil penelitian hubungan antara peraan kelompok tani dengan produktivitas usahatani madu adalah berhubungan positif dapat mendorong meningkatkan produksi madu yang dihasilkan. Semakin baik peran kelompok tani madu dalam produksi yang dilakukan oleh kelompok tani, maka semakin baik pula produktivitas madunya. Produktivitas adalah ukuran yang menyatakan berapa banyak input yang dibutuhkan untuk menghasilkan sejumlah output, produktivitas didefinisikan dengan ratio antara pengukuran output dengan masukan atau input (Abdullah 1979), biasanya merupakan pengukuran ratarata yang dirujukan dengan total output dibagi total input dari sumber daya khusus (Colinvaux 1993). Hal ini sesuai dengan pernyataan Nainggolan et al (2014) yang menyatakan kelompok tani merupakan kumpulan petani yang yang dikeluarkan adalah modal sendiri/pribadi dari petani tanpa ada pinjaman atau bantuan dari pihak lain.

\section{Hubungan Antara Peran Kelompok Tani Madu dengan Produktivitas Madu}

Berdasarkan hasil rekapitulasi hasil wawancara dengan responden tentang hubungan antara peran kelompok tani dengan produktivitas usahatani dapat dilihat pada Tabel 5 dibawah ini. tumbuh berdasarkan keakraban dan keserasian, serta kesamaan kepentingan dalam memanfaatkan sumberdaya pertanian untuk bekerjasama meningkatkan produktivitas usahatani dan kesejahteraan anggotanya.

\section{Kesimpulan}

1. Proses pengelolaan madu hutan yang dilakukan oleh kelompok tani APDS dilakukan sesuai dengan tahapannya yaitu dari awal pemasangan tikung sampai dengan pasca panen yang berupa teknik-teknik tikung, syaratsyarat pemanenan madu hutan dan proses panen madu. Jenis kayu yang dipakai kelompok tani untuk pembuatan tikung adalah jenis kayu Tembesu (Fagraeae fragrans). Perlengkapan yang digunakan kelompok tani APDS dalam proses panen madu yaitu menggunakan pisau stainless, wadah untuk menyimpan madu, penutup muka 
dan akar kayu menyadin (tebaok). Proses panen madu yang dilakukan kelompok tani yaitu dilakukan pada siang hari.

2. Peran kelompok tani dalam pengelolaan madu lebah hutan (Apis dorsata fabricius) di Dusun Batu Rawan Semangit sangat berperan penting dalam kelembagaan, produksi dan modalnya. Kelompok tani berperan dalam kelembagaan yaitu sebagai wadah belajar mengajar bagi anggotanya, tempat untuk memperkuat kerjasama petani, memiliki kemampuan mengambil keputusan dalam menentukan pengembangan produksi. Kelompok tani berperan dalam meningkatkan produksi madunya yaitu menggunakan sistem tiris dan teknik panen lestari. Kelompok tani berperan dalam modal yaitu kelompok tani mendapatkan modal utama secara swadaya dari anggota.

3. Hubungan antara peran kelompok tani dengan produktivitas usahatani madu di Dusun Batu Rawan Semangit berhubungan positif dapat mendorong meningkatkan produksi madu yang dihasilkan. Semakin baik peran kelompok tani madu dalam produksi yang dilakukan oleh kelompok tani, maka semakin baik pula produktivitas madunya

\section{Saran}

1. Perlu dilakukan penelitian lebih lanjut untuk peran kelompok tani dalam hal pemasaran atau penjualan madu lebah hutan APDS baik didalam maupun luar negeri untuk melihat bagaimana peran kelompok tani selaku produsen dalam memasarankan atau menjual produk madu lebah hutan kepada para konsumennya.

\section{DAFTAR PUSTAKA}

Assauri, Sofyan. 2008. Manajemen Produksi dan Operasi. Edisi Revisi. Lembaga Penerbit Fakultas Ekonomi Universitas Indonesia.

Diba F, Hisbullah Y dan Zainal S. 2017. Pemanfaatan Produk Hasil Hutan Bukan Kayu di Hutan Desa Nanga Betung Kecamatan Boyan Tanjung Kabupaten Kapuas Hulu. Jurnal Prosiding Seminar Lignoselulosa.

Djiwandi. 1994. Pengaruh Dinamika Kelompok Tani Terhadap Kecepatan Adopsi Teknologi Usahatani di Kabupaten Sukoharjo.Prosiding Laporan Penelitian.

Fatriani, Rezekiah AA, dan Fitriani A. 2014. Analisa Usaha Lebah Madu Hutan Dan Kualitasnya. Jurnal Hutan Tropis/Volume 2 No. 1.

Gilarso, T. 1993. Pengantar Ekonomi Mikro, jilid . Yogyakarta: Kanisisus

Hariadi, Samsi Sinarru. 2011, Dinamika Kelompok (Teori dan Aplikasinya untuk Analisis Kebarhasilan Kelompok Tani sebagai Unit Belajar, Kerjasama, Produksi, dan Bisnis). Sekolah Pasca Sarjana UGM : Yogyakarta.

Hasanudin, S. 2003. Morfologi dan Anatomi Lebah. Penebar Swadaya. Jakarta.

Hapsari H, Djuwendah E, Supriyadi Y. 2018. Optimalisasi Manajemen 
Usaha Lebah Madu Untuk Meningkatkan Pendapatan Keluarga (Kasus Pada Kelompok Tani Sunda Mukti, Desa Cilengkrang, Kecamatan Cilengkrang, Kabupaten Bandung). Jurnal Aplikasi Ipteks Untuk Masyarakat/Vol. 7, No. 1: $46-50$.

Hermanto dan Swastika. 2011. Penguatan Kelompok Tani: Langkah Awal Peningkatan Kesejahteraan Petani. Analisis Kebijakan Pertanian/Volume 9 No. 4: 371-390.

Jamiat, Iskandar dan Idham M. 2019. Kearifan Lokal Masyarakat Dalam Melestarikan Lebah Madu Alam Dengan Teknik Tikung Di Kawasan Danau Siawan Belida Kapuas Hulu. Jurnal Hutan Lestari/Volume 7 (2): 743-752.

Kustiari, T, Djoko, S, Sumardjo, Pulungan, I. 2006. Faktor - Faktor Penentu Tingkat Kemampuan Petani dalam Mengelola Lahan Marjinal (Kasus di Desa Karangmaja, Kecamatan Karanggayam, Kabupaten Kebumen, Jawa Tengah). Jurnal Penyuluhan, Maret 2006, vol.2, No. 1. ISSN:1858-2664.

Mardikanto. 2003. Penyuluhan Pengembangan Pertanian UNS Press. Surakarta.

Mikael, H Gusti, Iskandar. 2015. Kearifan Lokal Masyarakat Desa Tunggul Boyok Dalam Pengelolaan Madu Alam di Kecamatan Bonti Kabupaten Sanggau. Jurnal Hutan Lestari/Vol 3 (1) : 80 -87.
Ostrom, E. 1986. An Agenda for The Study of Institutions. Public Choice 48: 3- 25.

Pratiwi, E. 2010. Strategi Pemasaran Industri Madu Pada PT Madu Pramuka di Kabupaten Batang. Skripsi Sarjana Fakultas Pertanian Universitas Sebelas Maret : Surakarta.

Purba, SMG. 2016. Fungsi Kelompok Tani Dalam Pemberdayaan Sosial Ekonomi. https www.google.co.id/url?sa=t\&rct=j $\underline{\& q=\& \text { esrc }}$ Diakses pada 16 Juli 2019.

Putra AAS, Wisadirana D, Mochtar H. 2016. Strategi Pemberdayaan Masyarakat Melalui Pengembangan Lebah Madu Kelompok Tani Tahura(KTT) (Studi Kasus di Desa Dilem Kecamatan Gondang Mojokerto). Wacana/Vol. 19, No. 1.

Rachim, A., Yoandra, A., Sebua, J., Radaimon, Ramli, Rintan dan Wazar. 2011. Manual Pengelolaan Madu Hutan Tesso Nilo Secara Lestari Melalui Pendekatan Sistem Kontrol Internal. Yayasan Tesso Nilo, WWF. Indonesia.

Riak Bumi. 2007. Dibalik Penyerahan Sertifikat Produk Organik Biocert oleh Menteri Kehutanan kepada Masyarakat Petani Madu Hutan Danau Sentarum. Suara Bekakak No. XVIII/Th7/April-Juni 2007.

Roslinda E. 2013. Peran dan Praktik Agroforestri Masyarakat Periau (Petani Madu Hutan) Dalam Pengelolaan Kawasan Hutan Konservasi. Prosiding Seminar Nasional Agroforestri 2013. 
Ruttan dan Hayami. 1984. Dilema Ekonomi Desa: Suatu Pendekatan Ekonomi Terhadap Perubahan Kelembagaan di Asia.Yayasan Obor Indonesia. Jakarta.

Salaka FJ , Nugroho B, Nurrochmat DR. 2012. Strategi Kebijakan Pemasaran Hasil Hutan Bukan Kayudi Kabupaten Seram Bagian Barat, Provinsi Maluku. Jurnal Analisis Kebijakan Kehutanan/Vol. 9 No. 1, April $2012: 50-65$.

Santoso, Imam. 2006. Eksistensi Kearifan Lokal Pada Petani Tepian Hutan Dalam Memelihara Kelestarian Ekosistem Sumber Daya Hutan. Jurnal Wawasan/Vol.11, No 3.

Sofia, Zaenal S dan Rosalinda E. 2017. Pengelolaan Madu Hutan Berbasis
Kearifan Lokal Masyarakat Di Desa Semalah Dan Desa Melemba Kawasan Danau Sentarum Kabupaten Kapuas Hulu. Jurnal Hutan Lestari/Volume 5 (2): 209-208.

Supranto, 2008. Statistik Teori dan Aplikasi. Jakarta: Penerbit Erlangga.

Syahyuti. 2007. Gabungan Kelompok Tani (Gapoktan) Sebagai Kelembagaan Ekonomi Kebijakan Pengembangan Di Perdesaan.

Wispinaldo A, Marhiansyah M, Arlita T. 2016. Peranan Kelompok Tani Dalam Pemanfaatan Madu Lebah Hutan Di Desa Sahilan Darussalam Kecamatan Gunung Sahilan Kabupaten Kampar Provinsi Riau. JOM Faperta $U R /$ Vol 3 No 2. 